\title{
Lentiviral vector-based therapy in head and neck cancer (Review)
}

\author{
DEEPAK UPRETI ${ }^{1}$, ALOK PATHAK ${ }^{2}$ and SAM K.P. KUNG ${ }^{1}$
}

Departments of ${ }^{1}$ Immunology and ${ }^{2}$ Surgery, Faculty of Medicine, University of Manitoba, Winnipeg, MB R3E 0T5, Canada

Received March 21, 2013; Accepted September 17, 2013

DOI: $10.3892 / 01.2013 .1652$

\begin{abstract}
Head and neck squamous cell carcinoma (HNSCC) is the sixth most common neoplasm worldwide. Despite advances in multimodality treatments involving surgery, radiation and chemotherapy, the five-year survival rate has remained at $\sim 50 \%$ for the past 35 years. Therefore, the early detection of recurrent or persistent disease is extremely important. Replication-incompetent HIV-1-based lentiviral vectors have emerged as powerful and safe tools for gene delivery. Commonly, HNSCC is a locoregional disease that presents at or close to the body surface. Thus, HNSCC is amendable to intratumoral injections of gene therapy vectors aimed at correcting defects associated with tumor suppressor genes to induce the direct cytotoxicity of cancer cells or immune modulation to promote antitumor immunity. Current investigations analyzing HNSCC gene mutations and stem cell markers and the cancer immunoediting concept are creating exciting therapeutic opportunities for lentiviral and other gene transfer vectors. The present review reports specific examples of the current applications of lentiviral vectors in HNSCC.
\end{abstract}

\section{Contents}

1. Introduction

2. Immunobiology of head and neck cancer

3. The cancer immunoediting concept

4. Emerging concepts in lentiviral vector use for the treatment of HNSCC

5. Concluding remarks

\section{Introduction}

Head and neck squamous cell carcinoma (HNSCC) arises in the upper aerodigestive tract and includes mouth, throat, larynx and neck lymph node cancer. HNSCC is the sixth

Correspondence to: Dr Sam K.P. Kung, Department of Immunology, University of Manitoba, Room 417, Apotex Center, 750 McDermot Avenue, Winnipeg, MB R3E 0T5, Canada

E-mail:kung@cc.umanitoba.ca

Key words: lentiviral vectors, head and neck cancers, immunotherapy most common neoplasm worldwide. Despite advances in multimodality treatments that involve surgery, radiation and chemotherapy, the five-year survival rate has remained at $\sim 50 \%$ for the past 35 years (1-3). Therefore, the follow-up protocols currently in practice do not appear to diagnose treatment failure and recurrence early enough. There is a requirement for the identification of favorable prognostic biomarkers and the development of improved therapy for the treatment of head and neck cancer patients.

In the last three decades, a substantial association, as well as a synergistic relationship, has been found between alcohol and tobacco use and the development of head and neck cancer (4-6). Although the etiology of alcohol-associated head and neck cancer is not fully understood, genetic changes in tumor suppressor genes are likely to attribute to the transformation from normal to cancer cells in the formation and progression of head and neck cancer (7). p53 is widely accepted as a key tumor suppressor gene due to its important roles in regulating the cell cycle, apoptosis and DNA repair (8). Therefore, mutations in p53 are often associated with predisposition to HNSCC (9). Studies by Agrawal et al and Stransky et al used next generation sequencing techniques to compare exon sequences of all the determined human genes in normal and tumor cells of the same individual. The two studies revealed that the NOTCH gene underwent mutation in $10-15 \%$ of HNSCC tumors, thus, representing the second most commonly mutated gene in HNSCC following p53. In head and neck cancer, insufficient NOTCH1 signaling blocks squamous cell differentiation and contributes to the continuous proliferation of these 'pro-cancer' cells $(10,11)$. One of the growth factor receptors that is highly upregulated and responsible for the growth and survival of HNSCC is the epidermal growth factor receptor (EGFR) (12-15). Activation of EGFR with its corresponding ligand leads to the activation of downstream signaling pathways, including RAS/MAP, ERK, PI3K/AKT, Janus kinase and phospholipase protein kinase. The simultaneous activation of these pathways attributes to carcinoma growth and survival $(16,17)$. Monoclonal antibodies against EGFR and EGFR tyrosine kinase inhibitors are two types of treatment options currently in use for HNSCC (18). However, not all patients exhibit similar responses to these treatments. It may be argued that additional growth survival pathways, including VEGF, HER2 and HER3 $(19,20)$, may function in an EGFR-independent manner.

Currently, there are two hypotheses that explain the tumorigenic potential of cancer cells in HNSCC. The stochastic model indicates that all cancer cells acquire equal potential 
to develop tumors. A cancer cell that initiates tumor formation is selected randomly or by its growth advantage acquired under specific microenvironments (21). By contrast, the cancer stem cell model demonstrates that not all cancer cells are tumorigenic. Only a rare population of cells in tumors shares stem cell traits, including self-renewal and multipotency, which exhibit the potential to form tumors (22). In a number of studies, distinctive markers have been reported in head and neck cancer as cancer stem cell markers. Prince et al reported that $\mathrm{CD} 44$ represented a marker for cancer stem cells in HNSCC, demonstrating that 5,000 $\mathrm{CD}_{4} 4^{+}$cells were sufficient to form tumors. By contrast, CD44- cells were unable to form tumors (23). Krishnamurthy et al reported another ALDH marker associated with stem cell properties in vivo. Over $80 \%$ of $\mathrm{ALDH}^{+} \mathrm{CD} 44$ cells developed into a tumor at a dose 10 times lower than that of ALDH-CD44-Lin cells when implanted in mice (24). Thus, identification of these cell types is advantageous for the early eradication of cancer from primary sites and the development of innovative strategies.

\section{Immunobiology of head and neck cancer}

The immune system is composed of a wide network of cells, tissues and organs that protect the host from bacteria, parasites, fungi, viruses and the growth of tumor cells. A rich immunological environment surrounds the site of the head and neck region. Therefore, few tumor cells are successful in 'escaping' from the immunological surveillance covered by effector cells, including T cells, natural killer (NK) cells and $\mathrm{B}$ cells (25). The surviving tumor cells gain resistance against the immune response and are capable of establishing tolerance to the immune competent environment. Surviving tumor cells not only interfere with the host immune system but are also able to convert the local microenvironment in their favor to evade the host immune system, including $\mathrm{T}$ and NK cells, via several mechanisms that include manipulation of its own immunogenicity and production of immunosuppressive molecules (26-28). T cells are important effector lymphocytes that play a vital role in cell-mediated cytotoxicity and regulation of adaptive immunity (29). A decrease in the absolute cell counts of specific T-cell subsets has been observed in HNSCC patients $(30,31)$. Activation of the T-cell receptor (TCR) of cytotoxic $\mathrm{T}$ cells requires specific recognition of the MHC class I/peptide complex. Therefore, HNSCC escapes cytotoxic $\mathrm{T}$ cell recognition via downregulation of MHC class I molecules $(32,33)$. The CD3 $\zeta$ chain is a component of the TCR signaling complex and its expression is essential for $\mathrm{T}$ and NK cell activation. Downregulation of the expression of the $\mathrm{CD} 3 \zeta$ chain molecule is observed in the negative regulation of TCR signaling $(34,35)$. As Th1 responses are favorable for controlling head and neck cancer $(10,36,37)$, production of the immunosuppressive cytokine, IL-10, suppresses the Th1 response and favors the Th2 response, promoting the growth of head and neck cancer (38). The regulatory $\mathrm{T}$ cell is an additional $\mathrm{T}$ cell subset that suppresses the immune response of other cells and induces tolerance to self-antigens to avoid autoimmunity (39). In head and neck cancer patients, increases in the number of these regulatory cells have been found to correlate with the observed immune suppression (40-42).
The differentiation and functional activities of diverse T-cell subsets are tightly regulated by the maturation and activation status of dendritic cells (DCs) (43-46). Steady state, immature DCs are tolerogenic, whereas mature DCs have acquired the ability to effectively stimulate specific T-cell subsets, including Th1, Th2 and Th17 (47). Of note, a number of defects in DC differentiation and function have been reported in HNSCC patients and are as follows: i) defective differentiation of mature DCs, where the presence of immature myeloid cells has been found to reduce the expression of MHC class II and costimulatory molecules, resulting in the abnormal differentiation of DCs $(26,48)$; ii) impairment of chemotaxis, whereby the migration ability of monocytes has been found to be defective in HNSCC, which may be due to the tumor-derived factors that suppress the migration of monocytes (49); and iii) defects in DC maturation, where the immunosuppressive effects of soluble factors released by HNSCC have been found to cause the impairment of DC function. A number of tumor-secreted factors have been reported, including IL-10, vascular endothelial growth factor and granulocyte macrophage colony stimulating factor (50). These factors function at various levels, including blocking the differentiation of monocytes, and impairing DC maturation and immune tolerance (51-53). NK cells are an additional subset of lymphocytes that highlight an important innate defense against various harmful stimuli, including viruses and tumors $(54,55)$. Recent studies have demonstrated the importance of NK-DC crosstalk in the regulation of antitumor immune responses (56). Defects in DC function in HNSCC may also contribute to the defects in NK cells and the number of NK cells observed in HNSCC malignancies (57).

\section{The cancer immunoediting concept}

The concept of 'cancer immunosurveillance' proposed by Thomas highlighted the important role of the immune system in fighting against cancer (58). However, over the past two decades the 'cancer immunosurveillance' hypothesis has been challenged by observations that revealed the controversial role of the immune system in the promotion of tumor formation (29). The concept of 'cancer immunoediting' has been proposed recently to address antitumor immunity, tumor dormancy and escape mechanisms of immune recognition (59). The cancer immunoediting model consists of three sequential phases (3E phases), elimination, equilibrium and escape. The elimination phase is described with regard to the immune surveillance hypothesis, where the immune system is dominant compared with cancer cells. The immune system recognizes the altered cellular activity and tumor antigens and ultimately, eliminates cancer cells. During this phase, the host is free from cancer and nascent cancer cells are destroyed by the immune system before they may transform into tumors. The equilibrium phase is the second phase in which the immune system and cancer cells equally fight for survival. Tumor growth is maintained and prolonged tumor dormancy creates an environment where a rare, small fraction of tumor cells acquire novel mutations that allow them to resist immune attack and enter the final phase. The escape phase is the final phase in which tumor cells are no longer recognized by the immune system. The 
continuous pressure of the immune system against the cancer cells switches the cells from the equilibrium phase to the escape phase. The cancer cells lose their tumor microenvironment favoring their growth and effectively blocking immune recognition. Thus, cells that survive throughout the process emerge as tumors and are visible in clinical tests $(59,60)$.

\section{Emerging concepts in lentiviral vector use for the treatment of HNSCC}

The cancer gene therapy approach presents a means to introduce therapeutic/cytotoxic genetic materials into cancer cells to correct defects by replacing/suppressing the effects of the mutated gene or to destroy the cancer cells without harming the surrounding normal cells. Viral gene delivery vector systems, primarily retroviral and adenoviral vectors, have been widely used in animal studies and clinical trials to date (61). With the advances that have been made in the understanding of gene mutations/functions in cancer biology and application of suitable gene delivery systems, the first successful retroviral gene therapy trial for the treatment of melanoma was reported in 2006 (62). In this study, adoptive transfer of autologous $\mathrm{T}$ lymphocytes, engineered to encode a TCR specific for tumor-associated antigens, successfully regressed metastatic melanoma in two out of 15 patients. In addition, the great potential of using a gene therapy approach was highlighted for the treatment of cancer patients. Commonly, HNSCC is a locoregional disease that presents at or close to the body surface. Therefore, it is amendable to intratumoral injection of gene therapy vectors that aim to correct defects associated with tumor suppressor genes, induce the direct cytotoxicity of cancer cells (including the suicidal HSV-Tk gene and oncolytic ONYX-015 adenovirus) or induce immune modulation (including MHC-B7) to promote T-cell recognition of tumor cells (63-66).

Replication-incompetent HIV-1-based lentiviral vectors have emerged as powerful and safe tools for gene delivery due to their ability to transduce dividing and non-dividing cells (67-70). This enables the integration of genes into the host genome to sustain stable transgene expression, pseudotyping with vesicular stomatitis virus glycoprotein (VSV-G) or other modified envelope proteins to efficiently transduce the cells of interest (71). These vectors are relatively less immunogenic when compared with adenoviral vectors. In addition, they exhibit a different preference for the sites of vector integration in the host genome DNA when compared with retroviral vectors (72), thus, rendering them less likely to transform specific transduced cells via insertional mutagenesis of the proto-oncogene/tumor suppressor gene. To date, the application of the lentivirus to the transduction of primary immune cells, including hematopoietic stem cells, NK cells and DCs $(71,73,74)$, has been successful, providing an additional platform for the genetic engineering of host immune cells to augment antitumor activities. At present, there are a limited number of studies that have analyzed the use of lentiviral vectors as a tool for the delivery of genes in HNSCC. However, accumulating experimental and preclinical data has highlighted the proof of principle for the treatment of head and neck cancer using lentiviral vectors. The present review focuses on the multiple applications of lentivirus mediated gene therapy for the treatment of head and neck cancer in various experimental settings. As the concepts of RNA interference, cancer stem cells and cancer immunoediting are growing, an exciting opportunity is emerging for the future application of lentiviral vectors in cancer gene therapy and immunotherapy settings.

Commonly, the primary HNSCC tumor is treated with radiation or surgery. Despite intensive local treatment, tumor recurrence and metastases to distant sites is inevitable. Metastatic tumors may therefore require an alternative approach, including chemotherapy and other targeted agent therapies (75). As the majority of patients succumb to their condition due to these two critical effects, targeting these key steps is likely to be important for prolonging the survival of cancer patients (76). Degradation of the extracellular matrix by matrix metalloproteinases (MMPs) facilitates the migration of cancer cells to the surrounding normal cellular environment (77-80), and is consistent with the invasion and metastasis process. These proteases assist the diffusion of cancer cells into the vascular and lymphatic systems via degradation of the tissue structure (81). Targeting these MMPs may be useful for the successful treatment of cancer patients. Sun et al silenced MMP-2 expression in laryngeal squamous cell carcinoma using lentiviral vectors. The authors observed that inhibition of these endopeptidases significantly impedes the invasion and growth of laryngeal squamous cancer cells (82). Cisplatin is commonly offered to patients with advanced stage head and neck cancer. However, there are numerous cases where chemotherapy treatment has failed due to the expression of resistance genes in tumors (83). These gene products expel the drugs from the cytoplasm and shorten the duration of chemical exposure to cancer cells. The development of drug-resistant tumor cells accounts for the failure of chemotherapy in the control of cancer cell metastasis. The ABC transporter family has been identified as an anticancer drug transporter family $(84,85)$ and among the transporters, ABCC 2 has been shown to be involved in resistance to anticancer drugs, including cisplatin (86). Xie et al demonstrated that siRNA targeting ABCC2 mediated by a lentivirus markedly increased the cellular concentration of cisplatin, thereby increasing the sensitivity of cisplatin against the cancer cells and reducing the growth of cancer cells in vivo and in vitro (83). Chemokine receptors are likely to be involved in the metastasis of tumors and are unregulated in several types of human tumor, including breast, melanoma, prostate and colon (87-89). A study conducted by Hong et al demonstrated that the downregulation of CXCR4 using a lentiviral vector induced the antiproliferative and anti-invasive effects in oral cancer cells. In an in vivo model, the authors constructed a lentiviral expression vector targeting CXCR-4 mRNA. Using this model, the expression of CXCR-4 was knocked down in two oral squamous cell lines, KB and KB0SSC-25 B. The results showed that the anti-invasive effect was 29.5 and $38.1 \%$ in KB and KB0SSC-25B cell lines, respectively, compared with that in control vector-infected cells. In addition, CXCR4 knockdown cells grew significantly slower than the vector-infected cells, confirming the antiproliferative effect (90). It is important to investigate whether these gene-silenced cells are likely to inhibit the migration of tumor cells to distant sites, and to identify the impact on the 
induction of antitumor immune responses in vivo. A study by Chen et al reported that ALDH1 functions as a putative marker for cancer stem cells in HNSCC (91). In addition, the authors revealed that BMi-1, initially identified as a proto-oncogene, is responsible for maintaining the self-renewal capacity of $\mathrm{HNSCC}^{-} \mathrm{ALDH} 1^{+}$cells. Using the lentivirus expression vector plVRNAi/sh-BMi-1, BMi-1 expression was knocked down in $\mathrm{ALDH}^{+}$cells. BMi-1-silenced $\mathrm{ALDH}^{+}$cells showed stronger chemotherapeutic effects, as well as increased efficacy for radiotherapy, in vivo (92).

The dual opposite functions of immune interactions with cancer are being increasingly reported. According to the $3 \mathrm{E}$ phases of the cancer immunoediting model, if cancer has progressed beyond the equilibrium phase, the immune system may provide support to the cancer progression process rather than eliminate the cancerous cells. It is therefore important to understand the interactions of the tumor microenvironment, various immune cell types and cancer cells when designing a strategy to augment antitumor responses. In head and neck cancer, the immune system is often compromised due to the production of various suppressive factors $(26,27)$ or malfunction of key immune cells. Head and neck cancer evades the host immune system via specific mechanisms, including the downregulation of HLA class I molecules $(93,94)$ or $\mathrm{CD} 3 \zeta$ in T cells. As the $\mathrm{CD} 3 \zeta$ chain is a subunit of the TCR complex, essential for signal transduction (25), T cells of HNSCC patients show compromised cytotoxic ability $(75,95)$, decreased proliferation when stimulated with IL-2 (25) and decreased production of proinflammatory cytokines, including IL-2 and IFN- $\gamma(96)$. Thus, restoration of a functional immune system may be useful for controlling disease progression and tumor growth in HNSCC patients. The design of therapeutic strategies that eliminate primary cancer cells (elimination phase) and augment the host immune system against cancer cells (equilibrium phase) are likely to reduce the growth of primary tumors and spreading of cancer cells to secondary locations. HIV-1 viral protein (vpr) is an accessory vpr required for importing the HIV-1 vpr-integrating complex into the nucleus of nondividing cells (97). In addition, the vpr protein alone induces cell cycle arrest and apoptosis in a variety of mammalian cells $(98,99)$. Our previous study determined the antitumor potential of HIV-1 vpr in an AT-84 mouse model of oral cancer (100). A single intratumoral injection of vpr-expressing lentiviral gene therapy vectors reduced the primary tumor volume significantly within 7-14 days (100) and complete regression of the AT-84 tumor was identified in $>40 \%$ of animals. In addition, the latter were protected from a secondary challenge of AT-84 tumor cells (100). It is possible that expression of the vpr protein induced apoptosis in the tumor cells and augmented the target recognition by tumor cells. The latter may trigger augmented adaptive anti-AT-84 responses in primary and secondary tumor challenges.

\section{Concluding remarks}

Current investigations analyzing HNSCC gene mutations and cancer stem cell markers and the cancer immunoediting concept establish exciting therapeutic opportunities for lentiviral and other gene transfer vectors. Genetic manipu- lation of effector immune cell responses at the elimination and equilibrium phases may be consistent with the regression of primary tumors and the restoration/augmentation of antitumor responses in HNSCC patients. Strategies aimed at the direct elimination of tumor cells and/or augmentation of antitumor responses to $\mathrm{T}$ cells, including the augmentation of Th1 and suppression of T-cell regulation functions or DC levels, may be useful for the boosting of the immune system to fight HNSCC cancer. The VSV-G has been widely used for pseudotyping lentiviral vector particles due to its stability, high titer and broad cell tropism in transduction. Development of novel envelope proteins for pseudotyping lentiviral vector particles is likely to be consistent with cell-type specific transductions in vivo. A Sindbis virus glycoprotein, capable of binding DC-SIGN protein, was created to specifically deliver genes of interest into DCs following the administration of in vivo viral vectors (101). Further modification of the Sindbis virus envelope protein to express either a Fc-binding protein A domain, a biotin-adaptor peptide or arginine-glycine-aspartic acid RGD peptide have been shown to support targeted cell type-specific transduction (102-104). The latter may be utilized to target DC or cancer stem cells in vivo. An important feature of lentiviral vectors is the ability of the viral integrase protein to integrate the genes of interest into the host genome, consistent with the efficient and long-term gene expression of transgenes in transduced cells. Although the preferred sites of integration appear to vary between the lentiviral and retroviral vectors, concern that the vector integrations may pose a risk of insertional mutagenesis remains. In applications that do not require long-term stable gene expression, integration-deficient lentiviral vectors (that harbor class I mutations of the HIV-1 integrase) for transient transgene expression may also provide a safer alternative to the current lentiviral-based therapies (105-108).

\section{Acknowledgements}

The current study was supported by grants from the Manitoba Medical Service Foundation and Health Science Center Foundation, University of Manitoba.

\section{References}

1. Ferlay J, Shin HR, Bray F, Forman D, Mathers C and Parkin DM: Estimates of worldwide burden of cancer in 2008: GLOBOCAN 2008. Int J Cancer 127: 2893-2917, 2010.

2. Parkin DM, Pisani P and Ferlay J: Global cancer statistics. CA Cancer J Clin 49: 33-64, 1999.

3. Parkin DM, Bray F, Ferlay J and Pisani P: Global cancer statistics, 2002. CA Cancer J Clin 55: 74-108, 2005.

4. Blot WJ, McLaughlin JK, Winn DM, Austin DF, Greenberg RS, Preston-Martin S, Bernstein L, Schoenberg JB, Stemhagen A and Fraumeni JF Jr: Smoking and drinking in relation to oral and pharyngeal cancer. Cancer Res 48: 3282-3287, 1988.

5. Franceschi S, Talamini R, Barra S, Barón AE, Negri E, Bidoli E, Serraino D and La Vecchia C: Smoking and drinking in relation to cancers of the oral cavity, pharynx, larynx, and esophagus in northern Italy. Cancer Res 50: 6502-6507, 1990.

6. Zheng TZ, Boyle P, Hu HF, Duan J, Jiang PJ, Ma DQ, Shui LP, Niu SR and MacMahon B: Tobacco smoking, alcohol consumption, and risk of oral cancer: a case-control study in Beijing, People's Republic of China. Cancer Causes Control 1: 173-179, 1990.

7. Choi S and Myers JN: Molecular pathogenesis of oral squamous cell carcinoma: implications for therapy. J Dent Res 87: 14-32, 2008. 
8. Bensaad $\mathrm{K}$ and Vousden KH: p53: new roles in metabolism. Trends Cell Biol 17: 286-291, 2007.

9. Lozano G and Zambetti GP: What have animal models taught us about the p53 pathway? J Pathol 205: 206-220, 2005.

10. Agarwal A, Rani M, Saha GK, Valarmathi TM, Bahadur S, Mohanti BK and Das SN: Disregulated expression of the Th2 cytokine gene in patients with intraoral squamous cell carcinoma. Immunol Invest 32: 17-30, 2003.

11. Stransky N, Egloff AM, Tward AD, Kostic AD, Cibulskis K, Sivachenko A, Kryukov GV, Lawrence MS, Sougnez C, McKenna A, et al: The mutational landscape of head and neck squamous cell carcinoma. Science 333: 1157-1160, 2011.

12. Grandis JR and Tweardy DJ: Elevated levels of transforming growth factor alpha and epidermal growth factor receptor messenger RNA are early markers of carcinogenesis in head and neck cancer. Cancer Res 53: 3579-3584, 1993.

13. Rubin Grandis J, Melhem MF, Gooding WE, Day R, Holst VA, Wagener MM, Drenning SD and Tweardy DJ: Levels of TGF-alpha and EGFR protein in head and neck squamous cell carcinoma and patient survival. J Natl Cancer Inst 90: 824-832, 1998.

14. Grandis JR and Tweardy DJ: TGF-alpha and EGFR in head and neck cancer. J Cell Biochem Suppl 17F: 188-191, 1993.

15. Herbst RS, Giaccone G, Schiller JH, Natale RB, Miller V, Manegold C, Scagliotti G, Rosell R, Oliff I, Reeves JA, et al: Gefitinib in combination with paclitaxel and carboplatin in advanced non-small-cell lung cancer: a phase III trial - INTACT 2. J Clin Oncol 22: 785-794, 2004.

16. Citri A and Yarden Y: EGF-ERBB signalling: towards the systems level. Nat Rev Mol Cell Biol 7: 505-516, 2006.

17. Kalyankrishna S and Grandis JR: Epidermal growth factor receptor biology in head and neck cancer. J Clin Oncol 24: 2666-2672, 2006 .

18. Ciardiello $\mathrm{F}$ and Tortora G: EGFR antagonists in cancer treatment. N Engl J Med 358: 1160-1174, 2008.

19. Saba NF, Shin DM and Khuri FR: Targeting angiogenesis in head and neck cancer. Curr Cancer Drug Targets 7: 643-649, 2007.

20. Wheeler DL, Huang S, Kruser TJ, Nechrebecki MM, Armstrong EA, Benavente S, Gondi V, Hsu KT and Harari PM: Mechanisms of acquired resistance to cetuximab: role of HER (ErbB) family members. Oncogene 27: 3944-3956, 2008.

21. Quintana E, Shackleton M, Sabel MS, Fullen DR, Johnson TM and Morrison SJ: Efficient tumour formation by single human melanoma cells. Nature 456: 593-598, 2008

22. Civenni G, Walter A, Kobert N, Mihic-Probst D, Zipser M Belloni B, Seifert B, Moch H, Dummer R, van den Broek M and Sommer L: Human CD271-positive melanoma stem cells associated with metastasis establish tumor heterogeneity and long-term growth. Cancer Res 71: 3098-3109, 2011.

23. Prince ME, Sivanandan R, Kaczorowski A, Wolf GT, Kaplan MJ, Dalerba P, Weissman IL, Clarke MF and Ailles LE: Identification of a subpopulation of cells with cancer stem cell properties in head and neck squamous cell carcinoma. Proc Natl Acad Sci USA 104: 973-978, 2007.

24. Krishnamurthy S, Dong Z, Vodopyanov D, et al: Endothelial cell-initiated signaling promotes the survival and self-renewal of cancer stem cells. Cancer Res 70: 9969-9978, 2010.

25. Whiteside TL: Immunobiology and immunotherapy of head and neck cancer. Curr Oncol Rep 3: 46-55, 2001.

26. Almand B, Resser JR, Lindman B, Nadaf S, Clark JI, Kwon ED, Carbone DP and Gabrilovich DI: Clinical significance of defective dendritic cell differentiation in cancer. Clin Cancer Res 6: 1755-1766, 2000.

27. Duray A, Demoulin S, Hubert P, Delvenne P and Saussez S: Immune suppression in head and neck cancers: a review. Clin Dev Immunol 2010: 701657, 2010

28. Saito T, Kuss I, Dworacki G, Gooding W, Johnson JT and Whiteside TL: Spontaneous ex vivo apoptosis of peripheral blood mononuclear cells in patients with head and neck cancer. Clin Cancer Res 5: 1263-1273, 1999.

29. Zamarron BF and Chen W: Dual roles of immune cells and their factors in cancer development and progression. Int J Biol Sci 7 : 651-658, 2011

30. Kuss I, Donnenberg AD, Gooding W and Whiteside TL: Effector $\mathrm{CD}^{+} \mathrm{CD} 45 \mathrm{RO}^{-} \mathrm{CD} 27^{\circ} \mathrm{T}$ cells have signalling defects in patients with squamous cell carcinoma of the head and neck. Br J Cancer 88: 223-230, 2003.

31. Kuss I, Hathaway B, Ferris RL, Gooding W and Whiteside TL: Decreased absolute counts of T lymphocyte subsets and their relation to disease in squamous cell carcinoma of the head and neck. Clin Cancer Res 10: 3755-3762, 2004.
32. Campoli M, Chang CC and Ferrone S: HLA class I antigen loss, tumor immune escape and immune selection. Vaccine 20 (Suppl 4): A40-A45, 2002.

33. Vora AR, Rodgers S, Parker AJ, Start R, Rees RC and Murray AK: An immunohistochemical study of altered immunomodulatory molecule expression in head and neck squamous cell carcinoma. Br J Cancer 76: 836-844, 1997.

34. Kulkarni DP, Wadia PP, Pradhan TN, Pathak AK and Chiplunkar SV: Mechanisms involved in the down-regulation of TCR zeta chain in tumor versus peripheral blood of oral cancer patients. Int J Cancer 124: 1605-1613, 2009.

35. Valitutti S, Müller S, Salio M and Lanzavecchia A: Degradation of T cell receptor (TCR)-CD3-zeta complexes after antigenic stimulation. J Exp Med 185: 1859-1864, 1997.

36. Sparano A, Lathers DM, Achille N, Petruzzelli GJ and Young MR: Modulation of Th1 and Th2 cytokine profiles and their association with advanced head and neck squamous cell carcinoma. Otolaryngol Head Neck Surg 131: 573-576, 2004.

37. Whiteside TL: Anti-tumor vaccines in head and neck cancer: targeting immune responses to the tumor. Curr Cancer Drug Targets 7: 633-642, 2007.

38. Jebreel A, Mistry D, Loke D, Dunn G, Hough V, Oliver K, Stafford N and Greenman J: Investigation of interleukin 10, 12 and 18 levels in patients with head and neck cancer. J Laryngol Otol 121: 246-252, 2007.

39. Shevach EM: Regulatory/suppressor T cells in health and disease. Arthritis Rheum 50: 2721-2724, 2004.

40. Cesana GC, DeRaffele G, Cohen S, Moroziewicz D, Mitcham J, Stoutenburg J, Cheung K, Hesdorffer C, Kim-Schulze S and Kaufman HL: Characterization of $\mathrm{CD}^{+}{ }^{+} \mathrm{CD} 25^{+}$regulatory T cells in patients treated with high-dose interleukin-2 for metastatic melanoma or renal cell carcinoma. J Clin Oncol 24: 1169-1177, 2006.

41. Mizukami Y, Kono K, Kawaguchi Y, Akaike H, Kamimura K, Sugai $\mathrm{H}$ and Fujii $\mathrm{H}$ : Localisation pattern of Foxp ${ }^{+}$regulatory $\mathrm{T}$ cells is associated with clinical behaviour in gastric cancer. Br J Cancer 98: 148-153, 2008

42. Strauss L, Bergmann C and Whiteside TL: Functional and phenotypic characteristics of $\mathrm{CD}^{+}{ }^{+} \mathrm{CD} 25$ highFoxp3 $3^{+}$Treg clones obtained from peripheral blood of patients with cancer. Int J Cancer 121: 2473-2483, 2007

43. André F, Chaput N, Schartz NE, Flament C, Aubert N, Bernard J, Lemonnier F, Raposo G, Escudier B, Hsu DH, et al: Exosomes as potent cell-free peptide-based vaccine. I. Dendritic cell-derived exosomes transfer functional MHC class I/peptide complexes to dendritic cells. J Immunol 172: 2126-2136, 2004

44. Mende I and Engleman EG: Breaking tolerance to tumors with dendritic cell-based immunotherapy. Ann NY Acad Sci 1058: 96-104, 2005

45. Steinman RM: Dendritic cells: understanding immunogenicity. Eur J Immunol 37 (Suppl 1): S53-S60, 2007.

46. Todryk S: A sense of tumour for the immune system. Immunology 107: 1-4, 2002.

47. Cools N, Ponsaerts P, Van Tendeloo VF and Berneman ZN: Balancing between immunity and tolerance: an interplay between dendritic cells, regulatory T cells, and effector T cells. J Leukoc Biol 82: 1365-1374, 2007.

48. Almand B, Clark JI, Nikitina E, van Beynen J, English NR, Knight SC,Carbone DP and Gabrilovich DI: Increased production of immature myeloid cells in cancer patients: a mechanism of immunosuppression in cancer. J Immunol 166: 678-689, 2001.

49. Tas MP, Simons PJ, Balm FJ and Drexhage HA: Depressed monocyte polarization and clustering of dendritic cells in patients with head and neck cancer: in vitro restoration of this immunosuppression by thymic hormones. Cancer Immunol Immunother 36: 108-114, 1993

50. Gabrilovich DI, Chen HL, Girgis KR, et al: Production of vascular endothelial growth factor by human tumors inhibits the functional maturation of dendritic cells. Nat Med 2: 1096-1103, 1996.

51. Allavena P,Piemonti L, Longoni D, Bernasconi S, Stoppacciaro A Ruco L and Mantovani A: IL-10 prevents the differentiation of monocytes to dendritic cells but promotes their maturation to macrophages. Eur J Immunol 28: 359-369, 1998.

52. Péguet-Navarro J, Moulon C, Caux C, Dalbiez-Gauthier C, Banchereau J and Schmitt D: Interleukin-10 inhibits the primary allogeneic $\mathrm{T}$ cell response to human epidermal Langerhans cells. Eur J Immunol 24: 884-891, 1994.

53. Steinbrink K, Wölfl M, Jonuleit H, Knop J and Enk AH: Induction of tolerance by IL-10-treated dendritic cells. J Immunol 159: 4772-4780, 1997 
54. Cerwenka A and Lanier LL: Natural killer cells, viruses and cancer. Nat Rev Immunol 1: 41-49, 2001.

55. Yokoyama WM, Kim S and French AR: The dynamic life of natural killer cells. Annu Rev Immunol 22: 405-429, 2004

56. Lee SC, Srivastava RM, López-Albaitero A, Ferrone S and Ferris RL: Natural killer (NK): dendritic cell (DC) cross talk induced by therapeutic monoclonal antibody triggers tumor antigen-specific T cell immunity. Immunol Res 50: 248-254, 2011.

57. González FM, Vargas JA, López-Cortijo C, Castejón R, Gorriz C, Ramírez-Camacho R, Millán I and Durántez A: Prognostic significance of natural killer cell activity in patients with laryngeal carcinoma. Arch Otolaryngol Head Neck Surg 124: 852-856, 1998

58. Thomas L: On immunosurveillance in human cancer. Yale J Biol Med. 55: 329-33, 1982.

59. Schreiber RD, Old LJ and Smyth MJ: Cancer immunoediting: integrating immunity's roles in cancer suppression and promotion. Science 331: 1565-1570, 2011.

60. Dunn GP, Bruce AT, Ikeda H, Old LJ and Schreiber RD: Cancer immunoediting: from immunosurveillance to tumor escape. Nat Immunol 3: 991-998, 2002

61. Vattemi E and Claudio PP: The feasibility of gene therapy in the treatment of head and neck cancer. Head Neck Oncol 1: 3, 2009.

62. Morgan RA, Dudley ME, Wunderlich JR, Hughes MS, Yang JC, Sherry RM, Royal RE, Topalian SL, Kammula US, Restifo NP, et al: Cancer regression in patients after transfer of genetically engineered lymphocytes. Science 314: 126-129, 2006.

63. Abuzeid WM, Li D and O'Malley BW Jr: Gene therapy for head and neck cancer. Adv Otorhinolaryngol 70: 141-151, 2011

64. De Costa AM and Young MR: Immunotherapy for head and neck cancer: advances and deficiencies. Anticancer Drugs 22 674-681, 2011.

65. Harrington KJ, Nutting CM and Pandha HS: Gene therapy for head and neck cancer. Cancer Metastasis Rev 24: 147-164, 2005.

66. O'Malley BW, Cope KA, Chen SH, Li D, Schwarta MR and Woo SL: Combination gene therapy for oral cancer in a murine model. Cancer Res 56: 1737-1741, 1996.

67. Case SS, Price MA, Jordan CT, Yu XJ, Wang L, Bauer G Haas DL, Xu D, Stripecke R, Naldini L, et al: Stable transduction of quiescent CD34(+)CD38(-) human hematopoietic cells by HIV-1-based lentiviral vectors. Proc Natl Acad Sci USA 96 : 2988-2993, 1999.

68. Chang LJ and Gay EE: The molecular genetics of lentiviral vectors - current and future perspectives. Curr Gene Ther 1: 237-251, 2001

69. Roe T, Reynolds TC, Yu G and Brown PO: Integration of murine leukemia virus DNA depends on mitosis. EMBO J 12 2099-2108, 1993.

70. Schroers R, Sinha I, Segall H, et al: Transduction of human PBMC-derived dendritic cells and macrophages by an HIV-1-based lentiviral vector system. Mol Ther 1: 171-179, 2000

71. Kung SK, An DS, Bonifacino A, Metzger ME, Ringpis GE, MaoSH,Chen IS and Donahue RE: Induction of transgene-specific immunological tolerance in myeloablated nonhuman primates using lentivirally transduced CD $34^{+}$progenitor cells. Mol Ther 8: 981-991, 2003

72. Montini E, Cesana D, Schmidt M, Sanvito F, Ponzoni M, Bartholomae C, Sergi Sergi L, Benedicenti F, Ambrosi A, Di Serio C, et al: Hematopoietic stem cell gene transfer in a tumor-prone mouse model uncovers low genotoxicity of lentiviral vector integration. Nat Biotechnol 24: 687-696, 2006.

73. Mahmood S, Kanwar N, Tran J, Zhang ML and Kung SK: SHP-1 phosphatase is a critical regulator in preventing natural killer cel self-killing. PLoS One 7: e44244, 2012

74. Tran J, Mahmood S, Carlyle JR and Kung SK: Altering the specificity of NK:target cell interactions by genetic manipulation of NK receptor expression on primary mouse NK cells. Vaccine 28 : 3767-3772, 2010

75. Hoffmann TK: Systemic therapy strategies for head-neck carcinomas: Current status. GMS Curr Top Otorhinolaryngol Head Neck Surg 11: Doc03, 2012 (In German).

76. Steeg PS: Metastasis suppressors alter the signal transduction of cancer cells. Nat Rev Cancer 3: 55-63, 2003.

77. Egeblad M and Werb Z: New functions for the matrix metalloproteinases in cancer progression. Nat Rev Cancer 2: 161-174, 2002.

78. Folgueras AR, Pendás AM, Sánchez LM and López-Otín C: Matrix metalloproteinases in cancer: from new functions to improved inhibition strategies. Int J Dev Biol 48: 411-424, 2004.
79. Noel A, Maillard C, Rocks N, Jost M, Chabottaux V, Sounni NE, Maquoi E, Cataldo D and Foidart JM: Membrane associated proteases and their inhibitors in tumour angiogenesis. J Clin Pathol 57: 577-584, 2004

80. Overall CM and López-Otín C: Strategies for MMP inhibition in cancer: innovations for the post-trial era. Nat Rev Cancer 2: 657-672, 2002.

81. Liotta LA, Tryggvason K, Garbisa S, Hart I, Foltz CM and Shafie S: Metastatic potential correlates with enzymatic degradation of basement membrane collagen. Nature 284: 67-68, 1980

82. Sun Y, Liu M, Yang B, Li B and Lu J: Role of siRNA silencing of MMP-2 gene on invasion and growth of laryngeal squamous cell carcinoma. Eur Arch Otorhinolaryngol 265: 1385-1391, 2008.

83. Xie SM, Fang WY, Liu Z, Wang SX, Li X, Liu TF, Xie WB and Yao KT: Lentivirus-mediated RNAi silencing targeting ABCC2 increasing the sensitivity of a human nasopharyngeal carcinoma cell line against cisplatin. J Transl Med 6: 55, 2008.

84. Siddik ZH: Cisplatin: mode of cytotoxic action and molecular basis of resistance. Oncogene 22: 7265-7279, 2003.

85. Dean M, Hamon Y and Chimini G: The human ATP-binding cassette (ABC) transporter superfamily. J Lipid Res 42: 1007-1017, 2001

86. Taniguchi K, Wada M, Kohno K, Nakamura T, Kawabe T, Kawakami M, Kagotani K, Okumura K, Akiyama S and Kuwano M: A human canalicular multispecific organic anion transporter (cMOAT) gene is overexpressed in cisplatin-resistant human cancer cell lines with decreased drug accumulation. Cancer Res 56: 4124-4129, 1996.

87. Balkwill F: The significance of cancer cell expression of the chemokine receptor CXCR4. Semin Cancer Biol 14: 171-179, 2004.

88. Kang H, Watkins G, Douglas-Jones A, Mansel RE and Jiang WG: The elevated level of CXCR4 is correlated with nodal metastasis of human breast cancer. Breast 14: 360-367, 2005.

89. Sokolowska-Wojdylo M, Wenzel J, Gaffal E, Lenz J, Speuser P, Erdmann S, Abuzahra F, Bowman E, Roszkiewicz J, Bieber T and Tüting T: Circulating clonal CLA(+) and CD4(+) T cells in Sezary syndrome express the skin-homing chemokine receptors CCR4 and CCR10 as well as the lymph node-homing chemokine receptor CCR7. Br J Dermatol 152: 258-264, 2005.

90. Hong JS, Pai HK, Hong KO, Kim MA, Kim JH, Lee JI, Hong SP and Hong SD: CXCR-4 knockdown by small interfering RNA inhibits cell proliferation and invasion of oral squamous cell carcinoma cells. J Oral Pathol Med 38: 214-219, 2009.

91. Chen YC, Chen YW, Hsu HS, Tseng LM, Huang PI, Lu KH, Chen DT, Tai LK, Yung MC, Chang SC, et al: Aldehyde dehydrogenase 1 is a putative marker for cancer stem cells in head and neck squamous cancer. Biochem Biophys Res Commun 385: 307-313, 2009

92. Chen YC, Chang CJ, Hsu HS, Chen YW, Tai LK, Tseng LM, Chiou GY, Chang SC, Kao SY, Chiou SH and Lo WL: Inhibition of tumorigenicity and enhancement of radiochemosensitivity in head and neck squamous cell cancer-derived ALDH1-positive cells by knockdown of Bmi-1. Oral Oncol 46: 158-165, 2010.

93. Badoual C, Sandoval F, Pere H, Hans S, Gey A, Merillon N, Van Ryswick C, Quintin-Colonna F, Bruneval P, Brasnu D, et al: Better understanding tumor-host interaction in head and neck cancer to improve the design and development of immunotherapeutic strategies. Head Neck 32: 946-958, 2010.

94. Young MR: Protective mechanisms of head and neck squamous cell carcinomas from immune assault. Head Neck 28: 462-470, 2006.

95. Hathaway B, Landsittel DP, Gooding W, Whiteside TL, Grandis JR, Siegfried JM, Bigbee WL and Ferris RL: Multiplexed analysis of serum cytokines as biomarkers in squamous cell carcinoma of the head and neck patients. Laryngoscope 115: $522-527,2005$

96. Reichert TE, Rabinowich H, Johnson JT and Whiteside TL: Mechanisms responsible for signaling and functional defects. J Immunother 21: 295-306, 1998.

97. Planelles V and Benichou S: Vpr and its interactions with cellular proteins. Curr Top Microbiol Immunol 339: 177-200, 2009.

98. Poon B, Jowett JB, Stewart SA, Armstrong RW, Rishton GM and Chen IS: Human immunodeficiency virus type $1 \mathrm{vpr}$ gene induces phenotypic effects similar to those of the DNA alkylating agent, nitrogen mustard. J Virol 71: 3961-3971, 1997.

99. Stewart SA, Poon B, Song JY and Chen IS: Human immunodeficiency virus type $1 \mathrm{vpr}$ induces apoptosis through caspase activation. J Virol 74: 3105-3111, 2000. 
100.Pang S, Kang MK, Kung S, et al: Anticancer effect of a lentiviral vector capable of expressing HIV-1 Vpr. Clin Cancer Res 7: 3567-3573, 2001.

101. Dai B, Yang L, Yang H, Hu B, Baltimore D and Wang P: HIV-1 Gag-specific immunity induced by a lentivector-based vaccine directed to dendritic cells. Proc Natl Acad Sci USA 106: 20382-20387, 2009

102. Morizono K, Xie Y, Ringpis GE, Johnson M, Nassanian H, Lee $\mathrm{B}, \mathrm{Wu} \mathrm{L}$ and Chen IS: Lentiviral vector retargeting to P-glycoprotein on metastatic melanoma through intravenous injection. Nat Med 11: 346-352, 2005.

103. Morizono K, Xie Y, Helguera G, Daniels TR, Lane TF, Penichet ML and Chen IS: A versatile targeting system with lentiviral vectors bearing the biotin-adaptor peptide. J Gene Med 11: 655-663, 2009.

104. Morizono K, Pariente N, Xie Y and Chen IS: Redirecting lentiviral vectors by insertion of integrin-tageting peptides into envelope proteins. J Gene Med 11: 549-558, 2009.
105. Saenz DT, Loewen N, Peretz M, Whitwam T, Barraza R, Howell KG, Holmes JM, Good $M$ and Poeschla EM: Unintegrated lentivirus DNA persistence and accessibility to expression in nondividing cells: analysis with class I integrase mutants. J Virol 78: 2906-2920, 2004.

106. Apolonia L, Waddington SN, Fernandes C, Ward NJ, Bouma G, Blundell MP, Thrasher AJ, Collins MK and Philpott NJ: Stable gene transfer to muscle using non-integrating lentiviral vectors. Mol Ther 15: 1947-1954, 2007.

107. Negri DR, Michelini Z, Baroncelli S, Spada M, Vendetti S, Buffa V, Bona R, Leone P, Klotman ME and Cara A: Successful immunization with a single injection of non-integrating lentiviral vector. Mol Ther 15: 1716-1723, 2007.

108. Rahim AA, Wong AM, Howe SJ, Buckley SM, Acosta-Saltos AD, Elston KE, Ward NJ, Philpott NJ, Cooper JD Anderson PN, et al: Efficient gene delivery to the adult and fetal CNS using pseudotyped non-integrating lentiviral vectors. Gene Ther 16: 509-520, 2009. 